\title{
Effect of Semen Collection Frequency and Scrotal Circumference on Semen Quality Parameters in Brahman x Local Crossbred Bulls
}

\section{Md. Mahbubur Rashid ${ }^{1 *}$, Md. Azharul Hoque ${ }^{1}$, Khan Shahidul Huque ${ }^{2}$, Abul Kashem Fazlul Haque BhuiYan ${ }^{1}$}

\author{
${ }^{1}$ Department of Animal Breeding and Genetics, Bangladesh Agricultural University, Mymensingh-2202, Bangla- \\ desh; ${ }^{2}$ Bangladesh Livestock Research Institute, Savar, Dhaka-1341, Bangladesh.
}

\begin{abstract}
Five Brahman crossbred bulls were ejaculated twice weekly (2x) and 5 bulls four times weekly (4x) for 16 weeks to determine the effect of ejaculation frequency on semen characteristics and sperm output. Each of 10 bulls was ejaculated 4 times weekly for 4 weeks to determine sperm output and the relationship between scrotal circumference and semen parameters. For $4 \mathrm{x}$ bulls as compared to $2 \mathrm{x}$ bulls, ejaculation volume was smaller $(\mathrm{P}<0.01)$ but sperm concentration per ejaculate and total progressive motile sperm (TPMS) output per week were greater $(\mathrm{P}<0.01)$. Weekly semen output was greater $(\mathrm{P}<0.01)$ in $4 \mathrm{x}$ bulls $(11.4 \mathrm{~mL})$ compared to $2 \mathrm{x}$ bulls $(7.99 \mathrm{~mL})$. Average weekly TPMS output for $4 \mathrm{x}$ bulls was 1.61 times higher compared to $2 \mathrm{x}$ bulls. Occurrence of total abnormalities, proximal droplets and tail abnormalities was higher $(\mathrm{P}<0.05)$ in $4 \mathrm{x}$ bulls as compared with $2 \mathrm{x}$ bulls. When $2 \mathrm{x}$ bulls were placed at $4 \mathrm{x}$ for 4 weeks, they produced numerically higher TPMS $\left(14.2 \times 10^{9}\right)$ per week than that $\left(12.8 \times 10^{9}\right)$ of continued $4 \mathrm{x}$ bulls. Scrotal circumference was highly correlated $(\mathrm{P}<0.01)$ with semen volume and TPMS per ejaculate while the correlations between scrotal circumference and sperm motility and scrotal circumference and sperm concentration were found at medium and weak levels, respectively. Therefore, it seems appropriate to recommend the collection of semen from Brahman crossbred breeding bulls at the rate of 4 ejaculates per week and recording of scrotal circumference as a criterion to select young bulls as sires.
\end{abstract}

Keywords | Ejaculation frequency, Sperm abnormality, Sperm output, Morphology, Motility

Editor | Kuldeep Dhama, Indian Veterinary Research Institute, Uttar Pradesh, India.

Received | June 19, 2015; Revised | October 16, 2015; Accepted | October 19, 2015; Published | November 08, 2015

*Correspondence | Md. Mahbubur Rashid, Bangladesh Agricultural University, Mymensingh-2202, Bangladesh; E-mail: rashidjas@yahoo.com

Citation | Rashid MM, Hoque MA, Huque KS, Bhuiyan AKFH (2015). Effect of semen collection frequency and scrotal circumference on semen quality param-

eters in Brahman x Local crossbred bulls. Adv. Anim. Vet. Sci. 3(12): 677-684.

DOI | http://dx.doi.org/10.14737/journal.aavs/2015/3.12.677.684

ISSN (Online) | 2307-8316; ISSN (Print) | 2309-3331

Copyright (C) 2015 Rashid et al. This is an open access article distributed under the Creative Commons Attribution License, which permits unrestricted use, distribution, and reproduction in any medium, provided the original work is properly cited.

\section{INTRODUCTION}

$\mathrm{T}$ he cattle population of Bangladesh is 23.30 million, which consists of Local zebu, Friesian- Local crossbred, Friesian-Sahiwal crossbred and Sahiwal-Local crossbred (DLS, 2013). Out of 6.9 million breedable cows and heifers, Friesian-Local crossbred contributes about 24\% (Huque et al., 2011). More than $80 \%$ of the breeding bulls used in national artificial insemination program are Friesian-Local crossbred. Therefore, the proportion of this dairy genotype increased in the cattle population rapidly which contributed to long term growth in the dairy sector (Jabbar, 2010). Due to absence of any beef type breed, local zebu cattle and Friesian-Local crossbred cattle are being used for beef production to meet huge demand of meat.
In the year of 2009, National beef cattle development program was undertaken for crossbreeding between local zebu cows and Brahman sires through artificial insemination. Thereafter, more than 10,000 Brahman crossbred cattle were born throughout the country. Greater utilization of genetically superior Brahman-Local crossbred bulls for flourishing beef industry can be achieved by frequent semen collection from them. Weekly collection of two ejaculates from breeding bulls is a common practice at Central Artificial Insemination Laboratory in Bangladesh. According to DAHDF (2014), semen stations must follow the norm of minimum two ejaculates per collection and minimum two collections per bull per week for taking at least 90 collections and 180 ejaculates annually from each adult bull. In previous studies, the effect of age and ejacula- 
tion frequency on semen characteristics and sperm output of young Angus, Hereford, Charolais and Friesian x Sahiwal crossbred bulls has been reported (Almquist and Cunningham, 1967; Almquist et al., 1976; Sattar and Mirza, 2002). However, a maximum number of collection per bull would depend on the individual capacity of the bull.

A positive correlation between testicular development and semen quality has been documented through various studies (Spitzer et al., 1988; Arteaga et al., 2001). Testicular size, weight, semen volume and motile sperm output of young or adult bulls have been reported to be highly correlated with in situ measurements of scrotal circumference (Latif et al., 2009; Ha et al., 2012). Scrotal circumference is intimately correlated to capacity of sperm production, number of sperms ejaculated and sperm reserves (Palasz et al., 1994). However, information related to optimum ejaculation frequency, semen characteristics, sperm output and scrotal circumference of Brahman $\mathrm{F}_{1}$ crossbred beef type bulls in hot and humid tropical regions including Bangladesh are scanty. Thus, this study was conducted to determine: (a) the effect of ejaculation frequency on the sperm characteristics and sperm output of Brahman $x$ Local $F_{1}$ crossbred bulls and to evaluate (b) the relationship between scrotal measurements and semen parameters.

\section{MATERIAL AND METHODS}

\section{Animal Management and Experiment Design}

Ten Brahman $\mathrm{x}$ Local $\mathrm{F}_{1}$ crossbred bulls, having average age of $28.0 \pm 4.0$ months, body weight of $460 \pm 20 \mathrm{~kg}$ and scrotal circumference of $33.4 \pm 1.8 \mathrm{~cm}$ were selected from the Central AI Laboratory of Central Cattle Breeding Station, Savar, Dhaka. The bulls were reared in a separate clean, dry and regularly washed-floor shed and maintained under similar feeding and management. Total required feed included 1/3 concentrates and 2/3 roughages. Bulls had free access to fresh water.

The bulls were then divided into 2 groups having 5 bulls in each group and assigned to a high $(4 \mathrm{x})$ and low $(2 \mathrm{x})$ ejaculation frequency. The average age, body weight and scrotal circumference of the bulls between high and low ejaculation frequency group were similar. Five bulls were ejaculated twice weekly $(2 \mathrm{x})$ on Sunday and 5 bulls four times weekly $(4 \mathrm{x})$ consisting of two successive ejaculations on Sunday and Thursday for a period of 16 weeks from April to July 2013 (Phase-1). After completion of 16 weeks collection period, each of the 10 bulls was ejaculated at $4 \mathrm{x}$ for 5 weeks and data for the last 4 weeks (Phase-2) were used to determine mean weekly semen and sperm output.

\section{Testicular Measurements}

Scrotal circumference was measured using a flexible metal- lic tape graduated in centimetre $(\mathrm{cm})$ around the greatest diameter of both testes and the scrotum maintaining the testicles toward the bottom of the scrotum by moderate digital pressure as described by Foote (1969).

\section{Semen Collection and Laboratory Evaluation}

To maximize sperm output per ejaculate, the bulls were allowed at least two false mount before collection of each ejaculate. The semen was collected in graduated tubes at homosexual mount using artificial vagina (AV). Each ejaculum was evaluated for volume, sperm concentration, total motility of sperm, progressive motility of sperm, total sperm, total motile sperm and total progressive motile sperm. First and $2^{\text {nd }}$ ejaculate of each bull on Sunday of $1^{\text {st }}$, $5^{\text {th }}, 9^{\text {th }}$ and $13^{\text {th }}$ week of 16 week experiment were evaluated to determine the percentage of spermatozoa with normal and abnormal morphology. When all bulls ejaculated at $4 x$ for 5 weeks, $1^{\text {st }}$ ejaculate of each bull on Sunday from each of last 4 weeks were also evaluated to determine the normal and abnormal spermatozoa.

The volume of fresh semen was recorded from the graduated mark of the semen collecting tube. The concentration of spermatozoa was determined by using Density Spectrophotometer (SDM-5, Minitüb, GmbH, Germany). Semen was diluted in cuvettes with $0.9 \%$ sodium chloride solution at the ratio of 1:100. The reading was recorded from the Density Spectrophotometer in million/mL. Total sperm per ejaculate was determined by multiplication of sperm concentration with volume of ejaculate and expressed as million per ejaculate. Total motile sperm and total progressive motile sperm per ejaculate were determined.

\section{Spermatozoa Motility Analysis}

Each fresh ejaculate was evaluated for percentage of motile spermatozoa (motility $>5 \mu \mathrm{m} / \mathrm{s}$ ) and percentage of progressive motile spermatozoa (motility $>20 \mu \mathrm{m} / \mathrm{s}$ ) using the Computer Assisted Semen Analysis (CASA-Plus) system-AndroVision (Minitüb, Tiefenbach, GmbH, Germany) was equipped with Zeiss Scope A1 phase contrast microscope (Zeiss, Germany), a camera, a mini-therm stage warmer, an image digitizer and a computer to store data. To estimate total motility and progressive motility, a small drop of raw semen $(20 \mu \mathrm{L})$ was diluted with physiological solution $(0.9 \% \mathrm{NaCl}$, Merck, Germany) using a dilution ratio of 1:25. One small drop of this diluted semen was placed on a clean pre-warmed glass slide maintained on a heating plate $\left(37^{\circ} \mathrm{C}\right)$, covered with a cover slip and examined under phase-contrast microscope Zeiss Scope A1 phase contrast microscope at 20x. Three to five randomly selected microscopic fields were scanned for each sample and 500-1000 sperms were assessed in each analysis (Massányi et al., 2008). 
Spermatozoa Morphology

The proportion of normal spermatozoa with respect to acrosome, midpiece and tail was evaluated in buffered formal saline-fixed semen. One or 2 drops of raw semen was diluted in $0.5 \mathrm{~mL}$ of buffered formol saline containing $0.2 \%$ glutaraldehyde. The buffered formol saline was prepared according to the procedure described by Perera (2005). A drop $(10 \mu \mathrm{L})$ of formol saline fixed semen was placed on a clean glass slide with a cover slip and the edged were soaked with tissue paper to remove excess fluid. The slide was then held for 5 minutes to allow spermatozoa to settle down and examined under a phase contrast microscope (400x) that was equipped with differential interference contrast (DIC) optics (Olympus, BH-2, Japan).

A total of 200 spermatozoa per sample were evaluated to determine the percentage of spermatozoa with normal and abnormal morphology and the abnormalities with respect to acrosome, midpiece and tail. The abnormalities were classified as head abnormalities (detached head, giant head, pyriform), midpiece abnormalities (presence of proximal cytoplasmic droplet and distal cytoplasmic droplet) and tail abnormalities (coiled tail, bent tail, DAG and folded tail). The abnormalities were recorded individually. The spermatozoa having no abnormalities with respect to acrosome, midpiece and tail were considered as normal spermatozoa. Percentages of proximal droplets, distal droplets, head abnormalities and tail abnormalities were determined according to Barth and Oko (1989).

\section{Statistical Analysis}

The data on semen parameters and morphology were subjected to analysis of variance using Proc. GLM to determine treatment effects. Semen parameters of $1^{\text {st }}$ and $2^{\text {nd }}$ ejaculate within the frequency of ejaculation were also compared. Pearson product-moment correlation coefficient analysis for pair-wise correlation was used to assess correlations between scrotal circumference and semen parameters. Regression analyses were used to evaluate the importance of scrotal circumference measurement on prediction of different semen parameters. All analyses were conducted using Statistical Analysis System (SAS, 2003). $\mathrm{P}$-values at $\mathrm{P}<0.05$ were considered as statistically significant.

\section{RESULTS}

Out of an expected number of 160 and 320 ejaculates from bulls of $2 x$ and 4x group, 159 and 304 were collected, respectively during the first 16 weeks semen collection period, which was $96.5 \%$ of total specified number of 480 . Ejaculation during false mount and or before the penis could be covered with the artificial vagina accounted for 1 failure in $2 x$ group and 2 failures in $4 x$ group, while 14 failures happened because of not giving second ejaculate by $4 \mathrm{x}$ bulls.

Table 1: Semen parameters (Mean $\pm \mathrm{SE}$ ) per ejaculate of Brahman crossbred bulls at different ejaculation frequency

\begin{tabular}{|llllllll} 
Ejaculation frequency & $\begin{array}{l}\text { Volume } \\
(\mathbf{m L})\end{array}$ & $\begin{array}{l}\text { Concentration } \\
(\mathbf{1 0} / \mathbf{m L})\end{array}$ & $\begin{array}{l}\text { TM } \\
\mathbf{( \% )}\end{array}$ & $\begin{array}{l}\text { PM } \\
\mathbf{( \% )}\end{array}$ & $\begin{array}{l}\text { TS } \\
(\mathbf{1 0})\end{array}$ & $\begin{array}{l}\text { TMS } \\
\left(\mathbf{1 0}^{6}\right)\end{array}$ & $\begin{array}{l}\text { TPMS } \\
\left(\mathbf{1 0}^{6}\right)\end{array}$ \\
\hline $2 \mathrm{x}$ & $4.02^{\mathrm{a}} \pm 0.13$ & $1379^{\mathrm{b}} \pm 32.2$ & $81.5 \pm 0.61$ & $67.1 \pm 0.85$ & $5578^{\mathrm{a}} \pm 232$ & $4584^{\mathrm{a}} \pm 199$ & $3804^{\mathrm{a}} \pm 176$ \\
\hline $\mathrm{x}$ & $3.00^{\mathrm{b}} \pm 0.08$ & $1543^{\mathrm{a}} \pm 24.0$ & $80.7 \pm 0.53$ & $67.1 \pm 0.68$ & $4658^{\mathrm{b}} \pm 151$ & $3818^{\mathrm{b}} \pm 131$ & $3202^{\mathrm{b}} \pm 117$ \\
$\mathrm{SEM}$ & 0.07 & 19.6 & 0.40 & 0.53 & 129 & 111 & 98.2 \\
\hline $\mathrm{P}-$ value & $<.0001$ & $<.0001$ & 0.37 & 0.95 & 0.0007 & 0.001 & 0.0035
\end{tabular}

TM=Total motility; PM=Progressive motility; TS=Total sperm; TMS=Total motile sperm; TPMS=Total progressive motile sperm; SEM= Standard error of mean; ${ }^{\text {a,b }}$ Values with different superscript in a column differ significantly $(\mathrm{P}<0.05)$

Table 2: Semen parameters of $1^{\text {st }}$ and $2^{\text {nd }}$ ejaculate within frequency of ejaculation

\begin{tabular}{lllllllll} 
Ejaculation frequency & \multicolumn{4}{c}{ 2x ejaculation } & \multicolumn{5}{c}{ 4x ejaculation } \\
Parameters & $\begin{array}{l}1^{\text {st }} \text { ejaculate } \\
(\mathrm{n}=80)\end{array}$ & $\begin{array}{l}2^{\text {nd }} \text { ejaculate } \\
(\mathrm{n}=79)\end{array}$ & SEM & P-value & $\begin{array}{l}1^{\text {st }} \text { ejaculate } \\
(\mathrm{n}=157)\end{array}$ & $\begin{array}{l}2^{\text {nd }} \text { ejaculate } \\
(\mathrm{n}=147)\end{array}$ & SEM & P-value \\
\hline Volume $(\mathrm{mL})$ & 4.23 & 3.81 & 0.13 & 0.11 & $3.18^{\mathrm{a}}$ & $2.8^{\mathrm{b}}$ & 0.08 & 0.025 \\
\hline Concentration $\left(10^{6} / \mathrm{mL}\right)$ & $1445^{\mathrm{a}}$ & $1313^{\mathrm{b}}$ & 32.2 & 0.04 & 1571 & 1512 & 24.0 & 0.22 \\
\hline TM $(\%)$ & 81.4 & 81.5 & 0.61 & 0.93 & 80.8 & 80.6 & 0.53 & 0.85 \\
PM $(\%)$ & 66.9 & 67.3 & 0.85 & 0.81 & 67.0 & 67.1 & 0.68 & 0.94 \\
TS $\left(10^{6}\right)$ & $6174^{\mathrm{a}}$ & $4975^{\mathrm{b}}$ & 232 & 0.009 & $5040^{\mathrm{a}}$ & $4250^{\mathrm{b}}$ & 151 & 0.008 \\
\hline TMS $\left(10^{\mathrm{b}}\right)$ & $5088^{\mathrm{a}}$ & $4074^{\mathrm{b}}$ & 199 & 0.011 & $4129^{\mathrm{a}}$ & $3487^{\mathrm{b}}$ & 131 & 0.014 \\
TPMS $\left(10^{6}\right)$ & $4232^{\mathrm{a}}$ & $3371^{\mathrm{b}}$ & 176 & 0.014 & $3459^{\mathrm{a}}$ & $2928^{\mathrm{b}}$ & 117 & 0.022
\end{tabular}

TM=Total motility; PM=Progressive motility; TS=Total sperm; TMS=Total motile sperm; TPMS=Total progressive motile sperm; $\mathbf{S E M}=$ Standard error of mean; ${ }^{a, b}$ Values with different superscript in a column differ significantly $(\mathrm{P}<0.05)$ 


\section{VOLUME OF SEMEN}

Mean semen volume per ejaculate for $2 \mathrm{x}$ and $4 \mathrm{x}$ bulls are shown in Table 1. Ejaculate volume varied between ejaculation frequencies and among bulls within frequency $(\mathrm{P}<0.01)$. Mean ejaculate volume of $4.02 \mathrm{~mL}$ for the $2 \mathrm{x}$ bulls was larger $(\mathrm{P}<0.01)$ than that of 3.00 for $4 \mathrm{x}$ bulls.

For $4 \mathrm{x}$ bulls, the average of $3.18 \mathrm{~mL}$ for first ejaculate was greater $(\mathrm{P}<0.05)$ than that of $2.81 \mathrm{~mL}$ for second ejaculate, while $2 \mathrm{x}$ bulls did not show any variation between $1^{\text {st }}$ and $2^{\text {nd }}$ ejaculate volume (Table 2). Table 3 demonstrated that the weekly semen output for $4 \mathrm{x}$ bulls was larger $(\mathrm{P}<0.01)$ than that of $2 \mathrm{x}$ bulls. For bulls previously ejaculated at $2 \mathrm{x}$, weekly semen output at $4 \mathrm{x}$ averaged $14.2 \mathrm{~mL}$ in Phase-2. This value is higher than the average of $12.4 \mathrm{~mL}$ for the $4 \mathrm{x}$ bulls kept on $4 \mathrm{x}$ during the same period, but the difference was not significant.

\section{Sperm Concentration}

Sperm concentration varied $(\mathrm{P}<0.01)$ between ejaculation frequencies (Table 1) and among bulls within frequency

Table 3: Weekly sperm output from $2 \mathrm{x}$ and $4 \mathrm{x}$ bulls ( $\mathrm{n}=80$ )

\begin{tabular}{|lllll}
$\begin{array}{l}\text { Ejaculation } \\
\text { frequency }\end{array}$ & $\begin{array}{l}\text { Volume } \\
(\mathbf{m L})\end{array}$ & TS $_{\left(\mathbf{1 0}^{6}\right)}$ & $\begin{array}{l}\text { TMS } \\
\left.\mathbf{( 1 0}^{6}\right)\end{array}$ & $\begin{array}{l}\text { TPMS } \\
\left.\mathbf{( 1 0}^{6}\right)\end{array}$ \\
\hline $2 \mathrm{x}$ & $7.99^{\mathrm{b}}$ & $11086^{\mathrm{b}}$ & $9111^{\mathrm{b}}$ & $7561^{\mathrm{b}}$ \\
\hline $\mathrm{x}$ & $11.4^{\mathrm{a}}$ & $17701^{\mathrm{a}}$ & $14510^{\mathrm{a}}$ & $12167^{\mathrm{a}}$ \\
\hline $\mathrm{SEM}$ & 0.38 & 705 & 601 & 536 \\
\hline P-value & $<.0001$ & $<.0001$ & $<.0001$ & $<.0001$ \\
\hline
\end{tabular}

TM=Total motility; PM=Progressive motility; TS=Total sperm; TMS=Total motile sperm; TPMS=Total progressive motile sperm; SEM= Standard error of mean; ${ }^{a, b}$ Values with different superscript in a column differ significantly $(\mathrm{P}<0.05)$ (not presented). Mean concentration of $1543 \times 10^{6} \mathrm{sperm} /$ $\mathrm{mL}$ for the $4 \mathrm{x}$ bulls was superior $(\mathrm{P}<0.01)$ than that of $1379 \times 10^{6} \mathrm{sperm} / \mathrm{mL}$ for $2 \times$ bulls. In $2 \times$ bulls, the sperm concentration of $1^{\text {st }}$ ejaculate was greater $(\mathrm{P}<0.05)$ than that of $2^{\text {nd }}$ ejaculation while the corresponding values of sperm concentration for $4 \mathrm{x}$ bulls did not show any variation (Table 2). Table 8 indicated that when all bulls ejaculated at $4 x$, the sperm concentration per ejaculate did not vary between previous $2 \mathrm{x}$ group and $4 \mathrm{x}$ group.

\section{Sperm Motility}

Total motility and progressive motility of sperm were neither influenced by ejaculation frequency nor by the number of ejaculation within frequency (Table 1 and 2). On the other hand, total motility and progressive motility varied among bulls $(\mathrm{P}<0.01)$ of both groups except for progressive motility in $2 \mathrm{x}$ bulls (not presented). Progressive motility of $1^{\text {st }}$ ejaculation averaged 66.9 and $67.0 \%$ and $2^{\text {nd }}$ ejaculation averaged 67.3 and $67.1 \%$ in $2 \mathrm{x}$ and $4 \mathrm{x}$ bulls, respectively. In Phase-2, the total motility and progressive motility of sperm did not vary significantly between two groups.

\section{SPERm Output}

The mean of $5578 \times 10^{6}$ total perm (TS), $4584 \times 10^{6}$ total motile sperm (TMS) and $3804 \times 10^{6}$ total progressive motile sperm (TPMS) output per ejaculate for $2 \mathrm{x}$ bulls was greater $(\mathrm{P}<0.01)$ than that of $4658 \times 10^{6} \mathrm{TS}, 3818 \times 10^{6}$ MS and $3202 \times 10^{6}$ PMS output per ejaculate for $4 \mathrm{x}$ bulls (Table 1). Difference associated with ejaculation number within frequency (Table 2) and bulls within frequency (not presented) were significant $(\mathrm{P}<0.01)$. Weekly output of TS, TMS and TPMS differed significantly between ejaculation frequencies $(\mathrm{P}<0.01)$ and those of $4 \mathrm{x}$ bulls

Table 4: Morphological sperm abnormalities per ejaculate semen at $2 \mathrm{x}$ and $4 \mathrm{x}$ bulls $(\mathrm{n}=40)$

\begin{tabular}{|llllll}
$\begin{array}{l}\text { Ejaculation } \\
\text { frequency }\end{array}$ & $\begin{array}{l}\text { Head abnormalities } \\
(\mathbf{\%})\end{array}$ & $\begin{array}{l}\text { Proximal droplet } \\
(\mathbf{\%})\end{array}$ & $\begin{array}{l}\text { Distal droplet } \\
\mathbf{( \% )}\end{array}$ & $\begin{array}{l}\text { Tail abnormalities } \\
(\mathbf{\%})\end{array}$ & $\begin{array}{l}\text { Total abnormalities } \\
(\mathbf{\%})\end{array}$ \\
\hline $2 \mathrm{x}$ & 1.26 & $0.18^{\mathrm{b}}$ & 0.94 & $1.64^{\mathrm{b}}$ & $4.01^{\mathrm{b}}$ \\
\hline $4 \mathrm{x}$ & 1.69 & $0.51^{\mathrm{a}}$ & 1.06 & $2.51^{\mathrm{a}}$ & $5.78^{\mathrm{a}}$ \\
\hline $\mathrm{SEM}$ & 0.15 & 0.07 & 0.21 & 0.20 & 0.40 \\
\hline P-value & 0.15 & 0.014 & 0.76 & 0.026 & 0.026 \\
\hline
\end{tabular}

SEM= Standard error of mean; $\mathbf{n}=$ Number of observation of each treatment; a,b Values with different superscript in a column differ significantly $(\mathrm{P}<0.05)$

Table 5: Semen parameters per ejaculate of Brahman crossbred $2 \mathrm{x}$ and $4 \mathrm{x}$ bulls ejaculated at $4 \mathrm{x}(\mathrm{n}=80)$

\begin{tabular}{|llllllll} 
Ejaculation frequency & $\begin{array}{l}\text { Volume } \\
(\mathbf{m L})\end{array}$ & $\begin{array}{l}\text { Concentration } \\
(\mathbf{1 0} / \mathbf{m L})\end{array}$ & $\begin{array}{l}\text { TM } \\
\mathbf{( \% )}\end{array}$ & PM (\%) & TS $\left(\mathbf{1 0}^{6}\right)$ & $\begin{array}{l}\text { TMS } \\
\left(\mathbf{1 0}^{6}\right)\end{array}$ & TPMS $\left(\mathbf{1 0}^{6}\right)$ \\
\hline 2x bulls ejaculated at 4x & $3.56^{\mathrm{a}}$ & $1420^{\mathrm{b}}$ & 82.0 & 69.6 & 5001 & 4155 & 3540 \\
\hline 4x bulls remained at 4x & $3.10^{\mathrm{b}}$ & $1472^{\mathrm{a}}$ & 81.8 & 69.7 & 4531 & 3750 & 3211 \\
\hline SEM & 0.10 & 32.4 & 0.49 & 0.63 & 179 & 159 & 140 \\
P-value & 0.025 & 0.42 & 0.85 & 0.95 & 0.19 & 0.20 & 0.24
\end{tabular}

TM=Total motility; PM=Progressive motility; TS=Total sperm; TMS=Total motile sperm; TPMS=Total progressive motile sperm; $\mathrm{SEM}=$ Standard error of mean; ${ }^{\mathrm{a}, \mathrm{b}}$ Values with different superscript in a column differ significantly $(\mathrm{P}<0.05)$ 
Table 6: Semen parameters and output of 1 st and 2 nd ejaculate of all bulls ejaculated at $4 \mathrm{x}(\mathrm{n}=80)$

\begin{tabular}{|c|c|c|c|c|c|c|c|}
\hline Ejaculation number & Volume (mL) & Concentration $\left(10^{6} / \mathrm{mL}\right)$ & TM (\%) & PM (\%) & $\operatorname{TS}\left(10^{6}\right)$ & TMS (106) & TPMS $\left(10^{6}\right)$ \\
\hline $1^{\text {st }}$ ejaculate & 3.44 & 1431 & 81.5 & 69.3 & 4911 & 4058 & 3475 \\
\hline $2^{\text {nd }}$ ejaculate & 3.22 & 1461 & 82.2 & 70.0 & 4621 & 3847 & 3276 \\
\hline SEM & 0.10 & 32.4 & 0.49 & 0.63 & 179 & 159 & 140 \\
\hline $\mathrm{P}$-value & 0.28 & 0.63 & 0.47 & 0.56 & 0.42 & 0.51 & 0.47 \\
\hline
\end{tabular}

TM=Total motility; PM=Progressive motility; TS=Total sperm; TMS=Total motile sperm; TPMS=Total progressive motile sperm; SEM= Standard error of mean; ${ }^{\mathrm{a}, \mathrm{b}}$ Values with different superscript in a column differ significantly $(\mathrm{P}<0.05)$

Table 7: Comparative weekly sperm output of $2 \mathrm{x}$ and $4 \mathrm{x}$ bulls ejaculated at $4 x(n=20)$

\begin{tabular}{lllll}
$\begin{array}{l}\text { Ejaculation } \\
\text { frequency }\end{array}$ & $\begin{array}{l}\text { Volume } \\
(\mathbf{m L})\end{array}$ & $\begin{array}{l}\text { TS } \\
\left(\mathbf{1 0}^{6}\right)\end{array}$ & $\begin{array}{l}\text { TMS } \\
\left(\mathbf{1 0}^{6}\right)\end{array}$ & $\begin{array}{l}\text { TPMS } \\
\left.\mathbf{( 1 0}^{6}\right)\end{array}$ \\
\hline $\begin{array}{l}\text { 2x bull ejaculat- } \\
\text { ed at 4x }\end{array}$ & 14.2 & 20005 & 16620 & 14160 \\
\hline $\begin{array}{l}\text { 4x bull re- } \\
\text { mained at 4x }\end{array}$ & 12.4 & 18125 & 14998 & 12844 \\
\hline SEM & 0.53 & 908 & 848 & 801 \\
\hline p & 0.08 & 0.33 & 0.37 & 0.45
\end{tabular}

TM=Total motility; PM=Progressive motility; TS=Total sperm; TMS=Total motile sperm; TPMS=Total progressive motile sperm; SEM= Standard error of mean; ${ }^{a, b}$ Values with different superscript in a column differ significantly $(\mathrm{P}<0.05)$

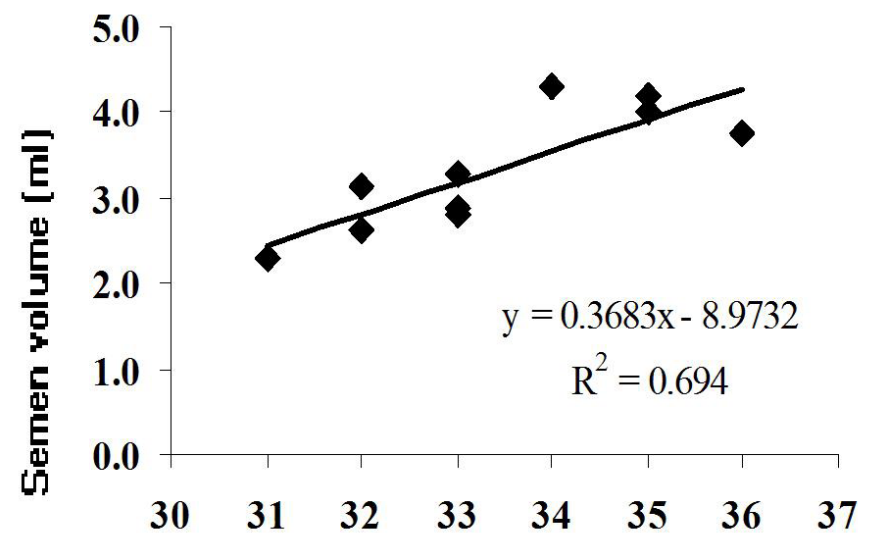

\section{Scrotal circumference (cm)}

Figure 1: Relationship between scrotal circumference and volume of semen per ejaculate

increased 1.60, 1.59 and 1.61 folds, respectively compared to those of $2 \mathrm{x}$ bulls (Table 3). When $2 \mathrm{x}$ bulls were placed on $4 \mathrm{x}$, weekly mean TS, TMS and TPMS were $20005 \times 10^{6}$ sperm, $16620 \times 10^{6}$ and $14160 \times 10^{6}$, respectively (Table 7). These values compared favorably to the corresponding values of $4 \mathrm{x}$ bulls maintained at $4 \mathrm{x}$ during the same period, but the differences were not significant (Table 7).

\section{Sperm Morphology}

Occurrence of total abnormalities, proximal droplet and tail abnormalities was higher $(\mathrm{P}<0.05)$ in $4 \mathrm{x}$ bulls as compared with $2 \mathrm{x}$ bulls (Table 4). Difference associated with number of ejaculation was not significant (not shown). When all bulls ejaculated at $4 \mathrm{x}$, only tail abnormalities showed discrepancy between two groups of bulls (Table 8). Overall sperm abnormalities in both groups were increased by double in Phase- 2 than that in Phase-1, except for proximal droplet.

\section{Relationship between Scrotal Circumference and Semen Parameters}

Pair wise correlation between scrotal circumference and semen parameters of all bulls ejaculated at $4 \mathrm{x}$ in Phase- 2 period are shown in Figure 1, 2, 3 and 4. The semen volume, TMS and TPMS per ejaculate seemed to be better in bulls with bigger scrotal circumference while sperm concentration and progressive motility of sperm did not show

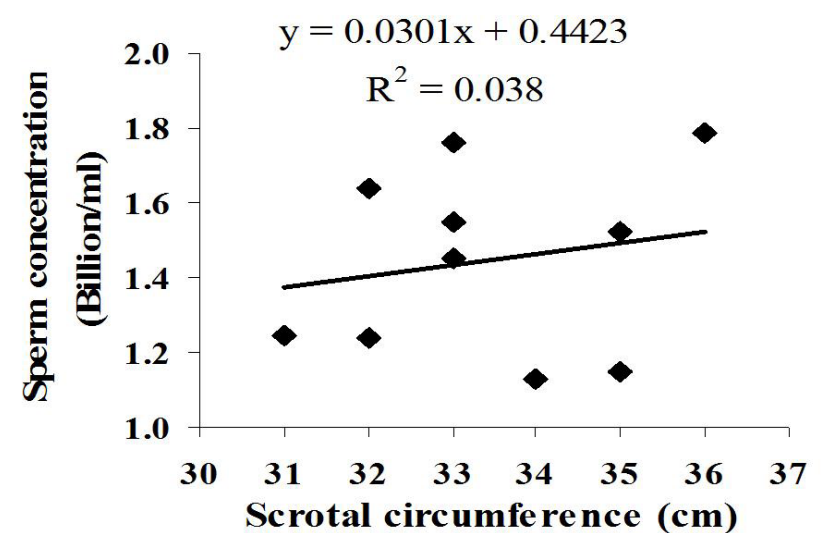

Figure 2: Relationship between scrotal circumference and sperm concentration

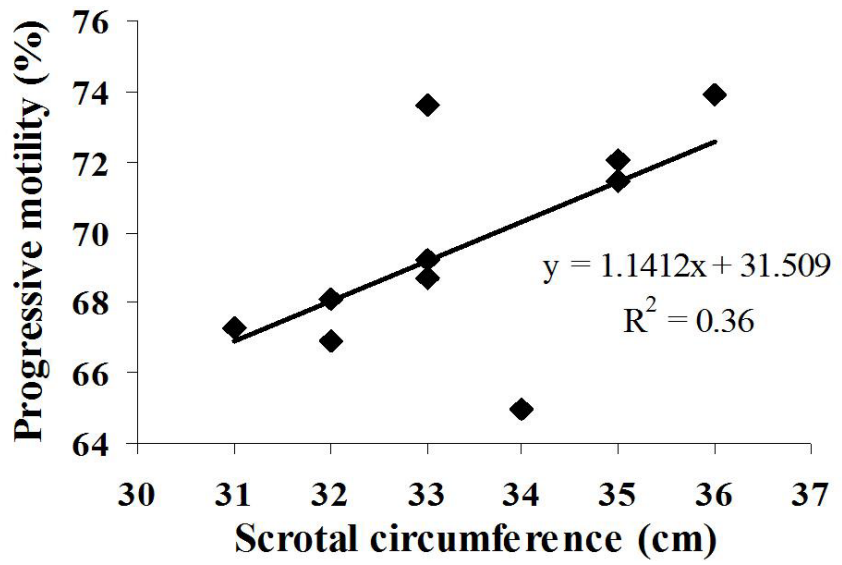

Figure 3: Relationship between scrotal circumference and progressive motility of semen 
Table 8: Morphological sperm abnormalities of $2 \mathrm{x}$ and $4 \mathrm{x}$ bulls ejaculated at $4 \mathrm{x}(\mathrm{n}=15)$

\begin{tabular}{|llllll|}
\hline Ejaculation frequency & $\begin{array}{l}\text { Head abnormalities } \\
\text { (\%) }\end{array}$ & $\begin{array}{l}\text { Proximal droplet } \\
\text { (\%) }\end{array}$ & $\begin{array}{l}\text { Distal droplet } \\
\text { (\%) }\end{array}$ & $\begin{array}{l}\text { Tail abnormalities } \\
\text { (\%) }\end{array}$ & $\begin{array}{l}\text { Total abnormalities } \\
\text { (\%) }\end{array}$ \\
\hline 2x bull ejaculated at 4x & 2.71 & 0.25 & 3.39 & $2.21^{\mathrm{b}}$ & 8.57 \\
\hline 4x bull remained at 4x & 3.07 & 0.40 & 2.67 & $5.77^{\mathrm{a}}$ & 11.9 \\
\hline SEM & 0.43 & 0.09 & 0.63 & 0.65 & 0.95 \\
\hline P-value & 0.68 & 0.39 & 0.57 & 0.004 & 0.08 \\
\hline
\end{tabular}

SEM= Standard error of mean; $\mathbf{n}=$ Number of observation of each treatment; ${ }^{\mathrm{a}, \mathrm{b}}$ Values with different superscript in a column differ significantly $(\mathrm{P}<0.05)$

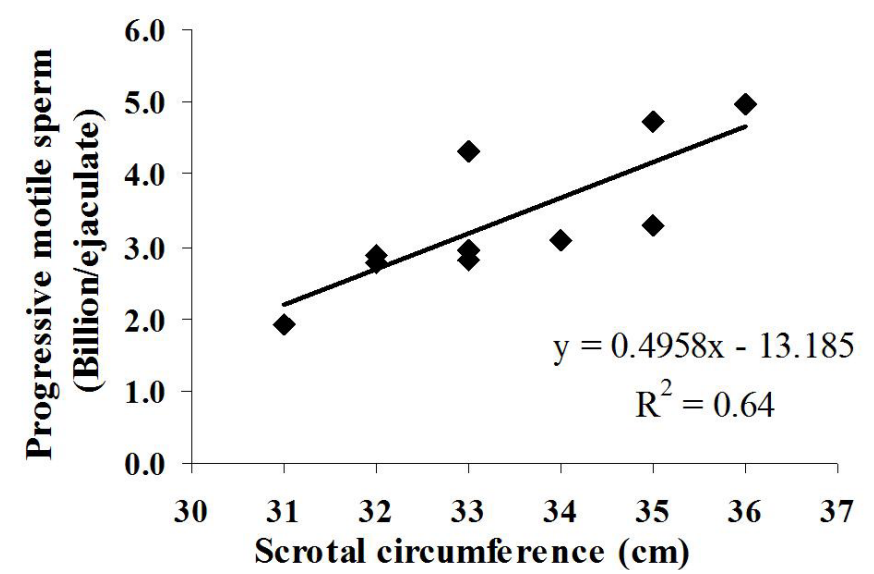

Figure 4: Relationship between scrotal circumference and progressive motile sperm per ejaculate

clear trend. The scrotal circumference had positive correlations with semen volume $(\mathrm{P}<0.01)$ and progressive motile sperm output and the determination coefficients were 0.69 and 0.64, respectively (Figure 1 and 4). Scrotal circumference also had positive influence to the progressive motility of sperm and sperm concentration, although correlations $\left(\mathrm{P}>0.05, \mathrm{R}^{2}=0.36\right.$ and 0.04 , respectively) were not as high as that on semen volume (Figure 3 and 2).

\section{DISCUSSION}

In this study, ejaculate volume and weekly semen output were significantly affected by bulls (although not shown) and ejaculation frequency. Volume of semen has been reported to be affected by the bulls and ejaculate number (Andrabi et al., 2002), and weekly semen output were influenced by frequency of semen collection (Sattar and Mirza, 2002). In 4x zebu and crossbred bulls, Shaha (2008) found that semen volume ranged from 4.1 to $7.6 \mathrm{~mL}$. Greater semen volume in $1^{\text {st }}$ ejaculate than $2^{\text {nd }}$ ejaculate of this study was consistent with the results of Andrabi et al. (2002) while Sattar and Mirza (2002) found no variation between $1^{\text {st }}$ and $2^{\text {nd }}$ ejaculates. On the contrary, Almquist et al. (1976) reported greater ejaculate volume $(3.3 \mathrm{~mL})$ in second ejaculations than that $(3.1 \mathrm{~mL})$ for first ejaculations in 6x Charolais bulls from 1 to 2 years of age $(\mathrm{P}<0.05)$. The present findings showed that weekly semen output of $4 \mathrm{x}$ bulls increased 1.43 times compared to $2 \mathrm{x}$ bulls. In comparison, Sattar and Mirza (2002) demonstrated increased semen output in 2 folds at $4 \mathrm{x}$ bulls than $2 \mathrm{x}$ bulls and Almquist et al. (1976) found 3.5 times more semen production in $6 \mathrm{x}$ bulls compared to $1 \mathrm{x}$ bulls $(\mathrm{P}<0.01)$. Greater sperm output in $4 \mathrm{x}$ bulls (1.6 times) compared to $2 \mathrm{x}$ bulls in the present study was fairly comparable to the results of Almquist et al. (1976) who reported that Charolais bulls ejaculated at $6 x$ yielded 3.3 times more motile sperm per week than ejaculation at $1 \mathrm{x}$ weekly.

In this study, sperm concentration was higher in $4 \mathrm{x}$ bulls than in $2 \mathrm{x}$ bulls, which was disagreed by Almquist et al. (1976) who found no influence of ejaculation frequency (1x vs 6x). Andrabi et al. (2002) obtained higher sperm concentration in $1^{\text {st }}$ ejaculate compared to $2^{\text {nd }}$ ejaculate in crossbred bulls ejaculated at $2 \mathrm{x}$ weekly, which supports our results. In contrast, greater $(\mathrm{P}<0.01)$ sperm concentration was found in $1^{\text {st }}$ ejaculate $\left(1.4 \times 10^{9} \mathrm{sperm} / \mathrm{mL}\right)$ than in $2^{\text {nd }}$ ejaculate $\left(1.2 \times 10^{9} \mathrm{sperm} / \mathrm{mL}\right)$ at $6 \mathrm{x}$ bulls (Almquist et al., 1976). The present study showed that motility of sperm was not affected by ejaculation frequency, which is in line with the results of Almquist et al. (1976) who evaluated $1 x$ and 6x bulls. Sattar and Mirza (2002) reported significantly higher sperm motility in $4 \mathrm{x}$ Friesian-Sahiwal crossbred bulls than that in $2 \mathrm{x}$ bulls. Better sperm motility was observed by Andrabi et al. (2002) in $1^{\text {st }}$ ejaculate than that in $2^{\text {nd }}$ ejaculate at $2 \mathrm{x}$ crossbred bulls whereas Almquist et al. (1976) reported greater motility in $2^{\text {nd }}$ ejaculate than that of $1^{\text {st }}$ ejaculate in 6x Charolais bulls $(\mathrm{P}<0.01)$. The differences between those studies and present work might be due to varied age or genotype and number of animals.

Proximal droplet arises in the epididymis and high percentage indicates maturation problem which might be common findings in bulls ejaculated at high frequency. Although $4 \mathrm{x}$ bulls showed higher abnormalities and proximal droplet, these are within acceptable range described by McGowan et al. (1995). Comparing with the present findings, Sattar and Mirza (2002) observed greater number of abnormal spermatozoa and tail abnormalities in $2 \mathrm{x}$ bulls than in $4 \mathrm{x}$ bulls while frequency of proximal and distal droplet did not vary between two. Sperm abnormalities were observed to be low in our study at Phase- 1 compared to the findings of Farooq et al. (2013) in Cholistani bulls and Ahsan et al. (2003) in pure Bos indicus and crossbred 
bulls. Overall sperm abnormalities in both groups ejaculated at $4 \mathrm{x}$ increased by double at Phase-2 (August) compared to $P$ hase- 1 period, which could be attributed to mainly nutrition factor (Chacon et al., 2002) or more humidity in that month or some others factors like- scrotal length and testicular consistency (Chacon, 2001).

The present results of positive correlations between scrotal circumference and semen parameters were supported by Ha et al. (2012) who demonstrated strong correlation of scrotal circumference with semen volume, sperm motility and total number of motile sperm in Holstein Friesian and Brahman bulls. Furthermore, significant positive correlations between scrotal circumference and weekly sperm output $(\mathrm{P}<0.01, \mathrm{r}=0.78)$ and between scrotal circumference and semen volume $(\mathrm{P}<0.05 ; \mathrm{r}=0.72)$ were reported by Almquist et al. (1976) and Latif et al. (2009), respectively. However, Siddiqui et al. (2008) concluded that crossbred bulls having bigger scrotum could produce better semen.

\section{CONCLUSION}

Ejaculation of Brahman $\mathrm{x}$ Local $\mathrm{F}_{1}$ crossbred breeding bulls at $4 \mathrm{x}$ weekly was not deleterious to semen traits and yielded 1.6 times more motile sperm output per week than ejaculation at $2 \mathrm{x}$ weekly. The scrotal circumference was highly correlated with semen volume and total progressive motile sperm per ejaculate. Therefore, it seems appropriate to recommend the collection of semen from Brahman $\mathrm{x}$ Local crossbred bulls at $4 \mathrm{x}$ weekly and the recording of scrotal circumference as a criterion to select young bulls as sires.

\section{ACKNOWLEDGEMENTS}

We acknowledge the award of a $\mathrm{PhD}$ grant of the National Agricultural Technology Project of the Department of Livestock Services financed by the World Bank to the first author, and the help and the cooperation of the authority of the Central AI Laboratory, especially, the continuous support of Md. Kutub Uddin Talukder.

\section{CONFLICT OF INTEREST}

There is no conflict of interest.

\section{AUTHORS' CONTRIBUTION}

All the authors contributed equally to this research paper.

\section{REFERENCES}

-Ahsan-ul-Haq, Mirza RH, Zahid IA (2003). Semen characteristics of crossbred (Friesian $x$ Sahiwal) and Sahiwal young bulls maintained under sub-tropical conditions of Panjab. Pakistan Vet. J. 23(2):100-102. http://www.pvj.com. pk/abstract/23_2/10.htm

-Almquist JO, Cunningham DC (1967). Reproductive capacity of beef bulls. I. Postpuberal changes in semen production at different ejaculation frequencies. J. Anim. Sci. 26: 174.

-Almquist JO, Branas RJ, Barber KA (1976). Testicular measurements and sperm output ejaculated at high frequency and the relation between postpuberal changes in semen production of Charolais bulls. J. Anim. Sci. 42: 670676. http://jas.fass.org/content/42/3/670

-Andrabi SMH, Naheed S, Khan LA, Ullah N (2002). Semen characteristics of crossbred (Friesian $\mathrm{x}$ Sahiwal) bulls at Livestock Research Station, National Agriculture Research Center, Islamabad. Pakistan Vet. J. 22(4).181-187. http:// www.pvj.com.pk/pdf-files/22_4/181-187.pdf

-Arteaga A, Baracaldo M, Barth AD (2001). The proportion of beef bulls in western Canada with mature spermiograms at 11 to 15 months of age. Can. Vet. J. 42: 783-787.

- Barth AD, Oko RJ (1989). Abnormal Morphology of Bovine Spermatozoa. Ames: Iowa State University Press. pp. 8-1 7.

- Chacon J (2001). Assessment of sperm morphology in zebu bulls under field conditions in tropics. Reprod. Domest Anim. 36: 91-99. http://dx.doi.org/10.1046/j.14390531.2001.00253.x

- Chacon J, Perez E, Rodriguez-Martinez H (2002). Seasonal variations in testicular consistency, scrotal circumference and spermiogramme parameters of extensively reared Brahman (Bos indicus) bulls in the tropics. Theriogenology. 58: 41-50. http://dx.doi.org/10.1016/S0093-691X(02)00679-9

-DAHDF (Department of Animal Husbandry, Dairying and Fisheries) (2014). Compendium of minimum standards of protocol and standard operating procedures for bovine breeding. Ministry of Agriculture, Government of India. Pp. 81.

-DLS (Department of Livestock Services) (2013). Annual report, Ministry of Fisheries and Livestock, Bangladesh.

- Farooq U, Ijaz A, Ahmad N, Rehman H, Zaneb H (2013). Investigations on semen quality and freezability of cholistani breeding bulls- a preliminary study from cholistan desert of Pakistan. J. Anim. Plant Sci. 23(2): 359-363. http://www.researchgate.net/ profile/Dr_Umer_Farooq/publication/259998217. INVESTIGATIONS_ON_SEMEN_QUALITY_ AND_FREEZABILITY_OF_CHOLISTANI_ BREEDING_BULLS_-A_PRELIMINARY_STUDY_ FROM_CHOLISTAN_DESERT_OF_PAKISTAN/ links/00b4952ef99011f924000000.pdf

- Foote RH (1969). Research techniques to study reproductive physiology in the male Techniques and Procedures in Animal Science Research, American Society of Animal Science, Albany, New York. pp: 81-110.

-Ha MT, Sac NH, Que LB, Hai PT, Tuan HM, Tiem PV, Hoa NTT, Kiem PV, Thong LV (2012). Relationship between scrotal circumference with some indicators of semen parameters in Holstein Friesian and Brahman breeding bulls. Livestock Research for Rural Development. 24(7). http://www.lrrd.org/lrrd24/7/ha24112.htm

-Huque KS, Dev GK, Jalil MA (2011). High yielding dairy breed development in Bangladesh- limitations and opportunities. Paper presented in international workshop on "High yielding dairy breed development in Bangladesh" held at Bangladesh Livestock Research Institute, Dhaka from 28-29 September, 
2011.

- Jabbar MA (2010). Policy barriers for dairy value chain development in Bangladesh with a focus on the North West region. A study for strengthening the dairy value chain in Bangladesh project of CARE Bangladesh, Dhaka. Pp.73.

-Latif MA, Ahmed JU, Bhuiyan MMU, Shamsuddin M (2009). Relationship between scrotal circumference and semen parameters in crossbred bulls. Bangladesh Vet. 26(2): 6167. http://www.banglajol.info/index.php/BVET/article/ view/4952

-Massányi P, Chrenek P, Lukáč N, Makarevich AV, Ostro A, Živčák J, Bulla J (2008). Comparison of different evaluation chambers for analysis of rabbit spermatozoa motility using CASA system. Slovak J. Anim. Sci. 41(2): 60-66.

-McGowan M, Galloway D, Taylor E, Entwistle K, Johnston P (1995). The Veterinary Examination of Bulls. Australian Association of Cattle Veterinarians, Indooroopilly, Q1d. ISBN 0646238434. from www.brahman.com.au/technical_ information/reproduction/semenEvaluation.html

-Palasz AT, Cates WF, Barth AD, Mapletoft RJ (1994). The relationship between scrotal circumference and quantitative testicular traits in yearling beef bulls. Theriogenology.42: 715-

726. http://dx.doi.org/10.1016/0093-691X(94)90388-Y

- Perera O (2005). Improving artificial breeding of cattle and buffalo in Asia, guidelines and recommendations. IAEATECDOC-1480.pp. 50.

-SAS (2003). SAS/STAT User's Guide: Version 9.3.1., SAS Institute Inc., Cary, North Carolina, USA.

- Sattar A, Mirza RH (2002). Effect of frequency of semen collection on semen characteristics in crossbred bulls at Livestock Experiment Station, Bhunikey (Pattoki), Distt. Kasur. J. Anim. Plant Sci. 12(4):126-128.

-Shaha SP, Alam MGS, Khatun M, Ahmed JU (2008). Breeding soundness of stud bulls. Bangladesh Vet.25(2): 51-61.http:// www.banglajol.info/index.php/BVET/article/view/4618

-Siddiqui MAR, Bhattacharjee J, Das ZC, Islam MM, Islam MA, Haque MA, Parrish JJ, Shamsudin M (2008). Cross bred bull selection for bigger scrotum and shorter age at puberty with potentials for better quality semen. Reprod. Domest. Anim. 43:74-79.

- Spitzer JC, Hopkins FM, Webster HW, Kirkpatrick FD, Hill HS (1988). Breeding soundness examination of yearling beef bulls. J. Am. Vet. Med. Asso. 193:1075-1079. 